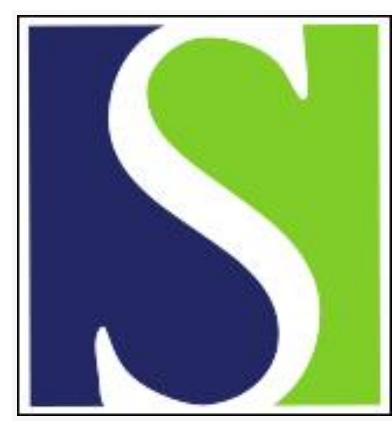

Scand J Work Environ Health 1995;21(2):124-133

https://doi.org/10.5271/sjweh.19

Issue date: Apr 1995

Relationship of pesticide spraying to signs and symptoms in Indonesian farmers

by Kishi M, Hirschhorn N, Djajadisastra M, Satterlee LN, Strowman S, Dilts $\mathrm{R}$

The following article refers to this text: 2002;28(6):371-385

Key terms: exposure; farmer; hazard grades; Indonesia; integrated pest management; pesticide spraying; poisoning; symptom; WHO; World Health Organisation

This article in PubMed: www.ncbi.nlm.nih.gov/pubmed/7618058 


\title{
Relationship of pesticide spraying to signs and symptoms in Indonesian farmers
}

\author{
by Misa Kishi, MD, ${ }^{1}$ Norbert Hirschhorn, MD, ${ }^{2,3}$ Marlinda Djajadisastra, ${ }^{1}$ Latifa N Satterlee, EngA, ${ }^{1}$ \\ Shelley Strowman, MA, ${ }^{2}$ Russell Dilts, EdD'
}

\begin{abstract}
Kishi M, Hirschhorn N, Djajadisastra M, Satterlee LN, Strowman S, Dilts R. Relationship of pesticide spraying to signs and symptoms in Indonesian farmers. Scand J Work Environ Health 1995;21:124-33.

Objectives This study assessed correlations between exposure to pesticides and signs and symptoms of pesticide toxicity among Indonesian farmers.

Methods Detailed observations were recorded of spray frequency and pesticide handling, dermal exposure, and the chemicals used. Symptoms of acute illness were reported by the farmers, and signs of poisoning were observed by the interviewers at the time of spraying or within a few hours after it.

Results The spray practices substantially exposed the farmers to pesticides. Signs and symptoms occurred significantly more often during spraying than during nonspraying seasons. Twenty-one percent of the spray operations resulted in three or more neurobehavioral, respiratory, and intestinal signs or symptoms. The number of spray operations per week, the use of hazardous pesticides, and skin and clothes being wetted with the spray solution were significantly and independently associated with the number of signs and symptoms. A dose-effect relationship was found between the neurobehavioral signs and symptoms and the use of multiple organophosphates.

Conclusions For farmers in the tropics, fully protective garb is too hot and too costly to maintain; farmers thus accept illness as a necessity. Integrated pest management has previously been demonstrated to reduce pesticide use with no loss of crop yield. The frequency of spraying should be reduced through widespread training in integrated pest management, and also the licensing and sale of the most hazardous pesticides should be regulated.
\end{abstract}

Key terms exposure, integrated pest management, poisoning, WHO hazard grades.

The World Health Organization (WHO) and the United Nations Environmental Program estimate that one to five million cases of pesticide poisoning occur among agricultural workers each year with about 20000 fatalities (1), the majority occurring in developing countries $(2,3)$. The true incidence of poisoning is likely to be considerably higher since the estimate is based on self-reported cases (4) or on inference from vital statistics (5).

In Indonesia, 265 different pesticides are registered (6), $44 \%$ of their active ingredients being in categories IA/IB/II (extremely, highly, and moderately hazardous, respectively) of the WHO hazard grades (7). In 1986, President Soeharto instructed that 28 broad-spectrum pesticides in 57 formulations be banned from use on rice because a pesticide-induced resurgence of brown plant- hopper threatened Indonesia's rice production $(8,9)$. Nearly $90 \%$ of the banned pesticides fall into categories IA/IB/II of the WHO hazard grades. The instruction also mandated that integrated pest management (IPM) become national policy for crop and plant protection.

The Indonesian National IPM Program has been widely recognized for its experiential "IPM farmer field school," where farmers become expert at analyzing the ecology of their fields and making sound field-management decisions. Over 200000 IPM-trained farmers now better understand the relationships between soil, plant, pest, and predator (9). Evaluations show that IPM-trained farmers use significantly less pesticide and fewer highly toxic pesticides, but still achieve equal or higher yields and capture greater profits than before (10). Because

1 Food and Agricultural Organization, Integrated Pest Management Program, Jakarta, Indonesia.

2 John Snow, Inc, Boston, Massachusetts, United States.

3 Currently at University of Minnesota School of Public Health, Minneapolis, Minnesota, United States.

Reprint requests to: Dr Norbert Hirschhorn, University of Minnesota School of Public Health, Box 97, 420 Delaware Street, SE, Minneapolis, MN 55455, USA. 
enforcement is incomplete and the banned pesticides are still legal for vegetable crops, the majority of Indonesia's 15 million farm households still have access to and use the banned pesticides, with continued risk to health. Another potential benefit of IPM, therefore, would be to reduce that risk, but, before one can speak knowledgeably about the risk in Indonesia, it seems important to demonstrate both to farmers and to policy makers the relationship between spray practices and ill health beyond retrospective reports and anecdotes.

Prospective epidemiologic studies linking illness and exposure are, however, difficult to carry out under field conditions (11). A recent large epidemiologic study in the United States still relied on retrospective and anecdotal information, and, while farmers had statistically lower erythrocyte cholinesterase levels, only a minimal association was shown with morbidity (12). The IPM Program in Indonesia is experienced in doing survey research, training interviewers, working with farmers in their fields, and handling the logistics of field operations, data management and analyses. We decided, therefore, on an alternative approach, that is, to observe and document farmers' spray practices in detail as they occurred, assess the immediate effects on their health, and establish the relationship between spray practices and health.

\section{Subjects and methods}

\section{Basic design and sample size}

This was a prospective cohort study with a purposive sampling frame. We studied farmers who farm both rice and vegetable crops on the same soil but in different seasons. Such persons have an approximate eight-week period during which farm work continues between the final spraying of the rice crop and the first spraying of the vegetable crop. Thus the frequencies of signs and symptoms in a prolonged no-spray period could be compared with frequencies during active spraying by the same persons. From the results of pilot studies, we estimated that the attack rates of signs and symptoms were about $15 \%$ in association with pesticide exposure, compared with background rates of about $5 \%$ in the absence of exposure. To detect this difference on one pair of interviews with a level of significance of $0.1 \%$ and a power of $80 \%$ (one-sided test) would require 213 persons per group (13). (The higher confidence level was considered necessary because multiple comparisons would be made of the attack rates.) A second consideration for sample size was the need to observe a sufficient number of individual spray operations so that individual exposure components could be reliably assessed against the relative risk of signs and symptoms; a sample of 407 spray operations is needed in each group to detect a relative risk of 2.0 (two-sided test, level of significance $0.1 \%$, power $90 \%$ ) (14).

\section{Study site and respondents}

The study took place in three villages of the Tegal and Brebes districts, Central Java, $320 \mathrm{~km}$ east of Jakarta. Censuses were conducted revealing a total farmer population of 5025. The following four criteria were applied for the recruitment of farmers: the farmer sprayed his or her own crops, planted rice in December-January, planted a shallot crop in March-May, and had fields that were no further than $5 \mathrm{~km}$ from home. Six hundred and twenty-five farmers met these criteria. On the basis of samplesize calculations and practical considerations, we recruited 204 farmers (203 men, 1 woman) and an additional 24 men who were professional sprayers. The latter held little or no land of their own. The average age of the respondents was 38.4 (SD 11.4) years. The average number of weekly scheduled interviews $(6.1$, SD 2.0$)$ per respondent was identical between the spray and nonspray seasons, and only $6 \%$ of the subjects dropped out of the study. Altogether 906 weekly observations were conducted in the spray season ( $84 \%$ of those scheduled), with 894 matched correctly to interviews on signs and symptoms at the same time. A second no-spray period, one year after the first, was also studied.

\section{Interviewers and field management}

Nineteen interviewers were recruited from a large pool of applicants. All were young men, local residents, and high school graduates, fluent in the local dialect. Twelve were themselves farmers. They were intensively trained in interview, observation and recording techniques. A monitoring team of four university graduates with experience in agriculture and extension-training supervised the interviewers. Each interviewer was responsible for 12 farmers, scheduling to observe spray operations of two farmers per day each week in adjacent fields. The monitors accompanied each interviewer once a week on a rotating basis to maintain the quality of the observations and interviews. They filled out parallel observation forms, and comparisons were made later. Approximately $8 \%$ of all interviews were validated this way. The monitors checked all forms daily for completeness. No differences in the quality of data were found between the farmer and nonfarmer interviewers. A secretariat was established in the town of Tegal to provide logistic and administrative support. A data-entry team carried out form control; coding and data entry were run twice by different persons. Desktop computers used Epi Info Version 5 (Centers for Disease Control, Atlanta, Georgia) as the file management software. 


\section{Glossary, signs and symptoms and exposure questionnaires 4}

In two pilot trials outside the study area, a glossary of signs and symptoms was developed from the descriptions of signs and symptoms farmers themselves gave as associated with pesticide use, along with local translations of signs and symptoms described in the public health literature $(15,16)$. A questionnaire listing 43 signs and symptoms was developed. Six items were included that are not typically associated with pesticide poisoning to control for nonspecific reporting of symptoms (constipation, cough, runny nose, abraded skin, blisters, muscle stiffness). A reported or observed acute sign or symptom was considered to be associated with the spray operation only if it began during or shortly after the spray operation (and, in the instance of insomnia, reported on follow-up the next day).

Each spray operation was observed and recorded on a detailed preprinted report form listing weather conditions, the mechanics of preparing the spray solution, the chemicals and utensils used, the volume of liquid formulations mixed in the field measured directly, the clothing and covering worn, observations of clothing and body contact with the spray solution, the spray procedures and condition of the equipment, food, drink and tobacco consumption, and cleanup. Farmers were also asked the number of spray operations carried out between the previous visit and the current one.

\section{Data analyses}

Differences between attack rates of signs and symptoms during nonspray and spray periods were calculated in $2 \times 2$ analyses, both across all spray operations and by averaging each farmer's experience. The relationships between the exposure variables and the frequency of signs and symptoms were examined in an analysis for linear trends (Mantel-Haenszel, chi square). We examined only those trends that looked promising, using the Statcalc feature of the Epi Info software, in order to minimize the number of comparisons. Modified Bonferroni adjustments were then made $(0.05 /$ number of comparisons) to derive P-values accepted for statistical significance (17). Standard multiple regressions (all variables entered at one step) were performed with PC-SAS (version 6.04). The dependent variable was the attack rate of signs and symptoms whose relative risk in the spray season was greater than 3.0. Predictor variables included in the regression were based on the analyses of linear association between exposure variables and the frequency of signs and symptoms. The active pesticide ingredient used by each farmer was indexed by WHO hazard grades: four points for every IB pesticide ("highly hazardous"), three for II ("moderately hazardous), two for III ("slightly hazardous"), one for 0 ("unlikely to present acute hazard in normal use") (7). (Captafol, the only IA pesticide used, was not indexed, as it has little acute toxicity aside from allergic dermatitis.) This index, therefore, reflects both the number and relative potency of pesticides used. Transformations of the data for normality changed the coefficients, partial correlations, and probabilities only minimally. Regression analyses were also obtained after each farmer's signs and symptoms, and exposure variables were averaged in order to neutralize the "design effect" of multiple comparisons in the same person.

\section{Household survey and follow-up of respondents}

At the close of the field study, all of the respondents were visited at home. Women who were high school graduates were recruited from the local area to observe where pesticides were stored and how, what use was made of pesticides and their containers, and how the farmer's clothing was washed. In addition, each farmer was asked if he had had any episode of "pesticide poisoning" - by his own definition - in the previous year. All of the respondents were offered enrollment into IPM field schools.

\section{Results}

\section{Exposure}

We considered the following four categories of exposure: the frequency and mechanics of the spray operations, the observed contact of the spray solution with the clothing and body, type of clothing worn, and the kinds of chemicals sprayed and their management. Each observed spray operation lasted 3 to $4 \mathrm{~h}$ on an average area of about 0.5 ha and consumed, on the average, the contents of five 17-1 back-pack tanks (up to 15 in a single spray operation), administered through a spray rod with manual pumping.

Table 1 shows the degree of exposure; an average of three spray operations per week, universal mixing of chemicals with bare hands, leaking equipment in over half of spray operations, an average of nearly four pesticides combined in each tank (up to 12) with half in categories IA/IB/II of the WHO hazard grades (table 2), and considerable wetting of bare skin and clothes with little washdown immediately after. A remarkable feature was the common use of pesticide "cocktails" in which several pesticides were mixed full strength in a container 
- often a narrow-mouthed bottle - and aliquots then diluted into the tank. No farmer wore industry-recommended protective clothing, and what clothing did cover the skin was mostly permeable cotton.

\section{Observed and reported signs and symptoms}

Sixty-nine different signs and symptoms were recorded, 43 from the original glossary and 26 reported additionally with low frequencies. Table 3 demonstrates the frequencies of the 43 signs and symptoms during the observed spray operations compared with their presence in weekly visits to the same respondents in the no-spray season. The respondents averaged nearly four signs and symptoms (range $0-15$ ), with at least one present in $99 \%$ of the spray operations. Thirty-seven of the signs and symptoms are typically associated with pesticide overexposure. Twenty-four of these had significantly higher frequencies in spray operations compared with the no-spray season (relative risks ranging from 2 to 48 ). The only nonspecific sign or symptom (used to control for reporting bias) to show a significant increase was muscle stiffness, a likely result of hauling spray tanks about. In $21 \%$ of the spray operations the respondents had three or more signs and symptoms from a panel of 12 neurobehavioral, intestinal, and respiratory items (matked in table 3 with an asterix), a functional criterion used by Keifer (18) for the retrospective diagnosis of organophosphate poisoning in Nicaragua.

The reporting of signs and symptoms was not affected by the duration of the study or the level of farmers' physical activity. In the following nonspray season several months later, the frequencies of signs and symptoms had returned to background levels. Since no standard definition of pesticide poisoning exists for epidemiologic purposes, we established a panel of 19 pesticideassociated signs and symptoms (italics in table 3 ) from those signs and symptoms whose relative risk of attack in the spray season exceeded 3.0, but we exempted flushed face, pallor, and burning nose (potentially nonspecific complaints), queasiness, and sore throat (less frequent than the related complaints of nausea and dry throat). The selection of the panel of 19 preceded the analyses of the relationship of attack rates of signs and symptoms to exposure and was thus not biased by the analyses.

The number of signs and symptoms from this panel averaged two per spray operation. The most serious sign was hand tremor, seen in 18 spray operations (16 different individuals). This subgroup averaged nearly five signs and symptoms per spray operation, significantly more than the rest of the spray operations $(t=6.2, \mathrm{P}<0.001)$. Averaging each farmer's experience did not remove the significance of the differences between the seasons except for itchy skin and hand tremor.
Table 1. Exposure variables used in the study.

\begin{tabular}{|c|c|c|}
\hline Variable & N & $\%$ \\
\hline \multicolumn{3}{|l|}{ Spray operation $(N=906)$} \\
\hline Sprays/week & $\begin{array}{c}2.8 \\
\text { (SD 0.9) }\end{array}$ & . \\
\hline Mixing with bare hand & & 100 \\
\hline Spraying against wind & . & 99 \\
\hline Leaking equipment & . & 58 \\
\hline Eating, drinking, smoking & . & 47 \\
\hline \multicolumn{3}{|l|}{ Chemicals used per spray operation } \\
\hline Chemicals & $5.0^{\mathrm{a}}$ & . \\
\hline Pesticides & 3.6 & \\
\hline \multicolumn{3}{|l|}{ WHO hazard grade } \\
\hline $\begin{array}{l}|A /| B /|| \\
|B /| \mid\end{array}$ & . & $\begin{array}{l}50 \\
44 \text { (see table 2) }\end{array}$ \\
\hline Pesticides in "cocktails" & . & 84 (see text) \\
\hline $\begin{array}{l}\text { Cocktail in narrow-neck } \\
\text { bottle }\end{array}$ & & 36 \\
\hline \multicolumn{3}{|l|}{ Clothing worn ( $\%$ of spray operations) } \\
\hline $\begin{array}{l}\text { Footgear } \\
\text { Gloves } \\
\text { Eyeglasses } \\
\text { Nose/mouth cover } \\
\text { Knee-high or long pants } \\
\text { Long-sleeved shirt } \\
\text { Headgear } \\
\text { Clothing unwashed since last spray }\end{array}$ & $\begin{array}{l}\dot{.} \\
\dot{.} \\
\dot{.} \\
\dot{.}\end{array}$ & $\begin{array}{l}0 \\
0.3 \\
5 \\
7 \text { (all cloth) } \\
42 \\
37 \\
99(69 \% \text { cloth }) \\
22\end{array}$ \\
\hline \multicolumn{3}{|l|}{$\begin{array}{l}\text { Observed contact of spray solution } \\
\text { with body, \% of spray operations }\end{array}$} \\
\hline $\begin{array}{l}\text { Hands/feet wetted on mixing } \\
\text { Hands/feet wetted on pouring } \\
\text { Splashed body during spray }\end{array}$ & . & $\begin{array}{l}90 / 10 \\
96 / 43 \\
78(83 \% \text { back, } \\
50 \% \text { waist, } \\
24 \% \text { shoulders, } \\
15 \% \text { hands, } \\
10 \% \text { neck, } \\
8 \% \text { legs and feet, } \\
3 \% \text { face) }\end{array}$ \\
\hline $\begin{array}{l}\text { Bathed/changed clothes soon } \\
\text { after spraying }\end{array}$ & & Otonos \\
\hline
\end{tabular}

a Nonpesticide chemicals were mostly surfactants: polyglycol, polyethoxy alcohol, and olefin derivatives.

\section{Relationship of signs and symptoms to exposure}

Matched observations of exposure and signs and symptoms were available for 894 spray operations. They were separated into three groups by the number of signs and symptoms from the panel of 19, approximating first, second and third, and fourth quartiles: none in 218 spray operations (24\%), group $1 ; 1-3$ in 481 spray operations (54\%), group 2; and 4-10 in 195 spray operations ( $22 \%)$, group 3 . There was no significant difference in the mean number of spray operations under observation per group. The mean ages of the three groups were similar. Of the 172 persons represented in group 2, 72 and 80 also appeared in groups 1 and 3, respectively; but only 16 persons appearing in group 1 also appeared in group 3 . The tendency of individuals to cluster within each of the three groups was statistically significant in an analysis of variance $(\mathrm{F}$-value $=5.0, \mathrm{P}<0.0001)$. 
Table 2. Pesticides used by the subjects in the study.

\begin{tabular}{|c|c|c|c|}
\hline $\begin{array}{l}\text { Pesticide } \\
\text { WHO grade }\end{array}$ & Chemical & Type of use & $\begin{array}{c}\text { Percentage of all } \\
\text { pesticides }\end{array}$ \\
\hline \multicolumn{4}{|l|}{ WHO grade $\mid A^{2}$} \\
\hline Captafol & Phthalimide & Fungicide & 6.1 \\
\hline \multicolumn{4}{|l|}{ WHO grade IB a } \\
\hline $\begin{array}{l}\text { Triazophos } \\
\text { Methamidophos } \\
\text { Fenthion } \\
\text { Methomyl } \\
\text { Monocrotophos } \\
\text { Methidathion } \\
\text { Zinc phosphide }\end{array}$ & $\begin{array}{l}\text { Organophosphate } \\
\text { Organophosphate } \\
\text { Organophosphate } \\
\text { Carbamate } \\
\text { Organophosphate } \\
\text { Organophosphate } \\
\text { Inorganic, compound }\end{array}$ & $\begin{array}{l}\text { Insecticide } \\
\text { Insecticide } \\
\text { Insecticide, larvicide } \\
\text { Insecticide } \\
\text { Insecticide } \\
\text { Insecticide } \\
\text { Rodenticide }\end{array}$ & $\begin{array}{l}6.1 \\
0.5 \\
0.3 \\
0.2 \\
0.09 \\
0.06 \\
0.06\end{array}$ \\
\hline \multicolumn{4}{|l|}{ WHO grade II a } \\
\hline $\begin{array}{l}\text { Fenobucarb (BPMC) } \\
\text { Chlorpyrifos } \\
\text { Profenofos } \\
\text { Endosulfan } \\
\text { Diazinon } \\
\text { Prothiophos } \\
\text { Dichlorodiphenyltrichloro- } \\
\text { ethane (DDT) } \\
\text { Fenitrothion } \\
\text { Phenthoate } \\
\text { Isoprocarb (MIPC) } \\
\text { Thiodicarb } \\
\text { Permethrin } \\
\text { Cyfluthrin }\end{array}$ & $\begin{array}{l}\text { Carbamate } \\
\text { Organophosphate } \\
\text { Organophosphate } \\
\text { Organophosphate } \\
\text { Organophosphate } \\
\text { Organophosphate } \\
\text { Organochloride } \\
\\
\text { Organophosphate } \\
\text { Organophosphate } \\
\text { Carbamate } \\
\text { Carbamate } \\
\text { Pyrethroid } \\
\text { Pyrethroid }\end{array}$ & $\begin{array}{l}\text { Insecticide } \\
\text { Insecticide } \\
\text { Insecticide } \\
\text { Insecticide } \\
\text { Insecticide } \\
\text { Insecticide } \\
\text { Insecticide } \\
\\
\text { Insecticide } \\
\text { Insecticide } \\
\text { Insecticide } \\
\text { Insecticide } \\
\text { Insecticide } \\
\text { Insecticide }\end{array}$ & $\begin{array}{l}18.8 \\
12.3 \\
2.0 \\
1.4 \\
1.3 \\
0.3 \\
0.2 \\
\\
0.2 \\
0.1 \\
0.06 \\
0.06 \\
0.03 \\
0.03\end{array}$ \\
\hline \multicolumn{4}{|l|}{ WHO grade III a } \\
\hline $\begin{array}{l}\text { Acephate } \\
\text { Pyridaphenthion } \\
\text { Copper hydroxide }\end{array}$ & $\begin{array}{l}\text { Organophosphate } \\
\text { Organophosphate } \\
\text { Inorganic, compound }\end{array}$ & $\begin{array}{l}\text { Insecticide } \\
\text { Insecticide } \\
\text { Fungicide }\end{array}$ & $\begin{array}{l}1.0 \\
0.1 \\
0.04\end{array}$ \\
\hline \multicolumn{4}{|l|}{ WHO grade $\mathrm{O}^{\text {a }}$} \\
\hline $\begin{array}{l}\text { Mancozeb } \\
\text { Propineb } \\
\text { Flufenuxuron } \\
\text { Iprodione } \\
\text { Oxyfluorfen } \\
\text { Captan } \\
\text { Maneb } \\
\text { Chlorothalonil } \\
\text { Chlorflurazuron } \\
\text { Thiophanate } \\
\text { Metobromuron }\end{array}$ & $\begin{array}{l}\text { Thiocarbamate } \\
\text { Thiocarbamate } \\
\text { Carboxamide } \\
\text {. } \\
\text { Phthalinide } \\
\text { Thiocarbamate } \\
\text { Nitrile } \\
.0 \\
\text { Carbamate } \\
.6\end{array}$ & $\begin{array}{l}\text { Fungicide } \\
\text { Herbicide } \\
\text { Insecticide } \\
\text { Fungicide } \\
\text { Herbicide } \\
\text { Fungicide } \\
\text { Fungicide } \\
\text { Fungicide } \\
\text { Insect growth regulator } \\
\text { Fungicide } \\
\text { Herbicide }\end{array}$ & $\begin{array}{r}14.1 \\
10.6 \\
6.8 \\
1.3 \\
1.0 \\
0.9 \\
0.7 \\
0.6 \\
0.07 \\
0.02 \\
0.02\end{array}$ \\
\hline
\end{tabular}

a $\mid A=$ extremely dangerous, $I B=$ highly dangerous, $\|=$ moderately dangerous, $I I=$ slightly dangerous, $0=$ not dangerous under normal use according to the World Health Organization (WHO). (See reference 7.) Danger may be accentuated by overconcentration, simultaneous use of pesticides with similar biological action, interactions, or other factors.

b Unclassified by WHO.

Nine exposure variables increased significantly from group 1 to group 3, as shown in table 4 . The major risk factors were frequency of spraying, six variables indicating excessive wetting of the skin with the solution, and the proportion and overdose of hazardous pesticides. The same exposure variables were significantly related to signs and symptoms when the Keifer panel of 12 were used to divide the spray operations into three groups $(0,1-2, \geq 3$ signs and symptoms).

Multiple regression analyses were performed to determine the contribution of exposure variables to the attack rate identified as significant in the trend analyses (table 5). The model with the highest $\mathrm{R}^{2}$ incorporated spray frequency, the six variables exposing sprayers to the absorption of pesticides through the skin, the pesticide index, and status as a professional pesticide sprayer. The P-values were statistically significant for spray frequency and skin exposure $(\mathrm{P}<0.000)$. Multiple regressions were also done using each farmer's average frequency of signs and symptoms and the average number of exposure variables to eliminate the bias of multiple observations on the same person. Spray frequency and skin exposure were again significant predictor variables.

Spray frequency, use of a greater number of hazardous pesticides, and skin exposure tended to occur together, showing small but significant correlation coefficients. Their interactive effects are further demonstrated in figure 1 . The pesticide index (PI) was combined with the 
Table 3. Reported a attack rate (\%) of observed and reported signs and symptoms.

\begin{tabular}{|c|c|c|c|c|c|}
\hline Signs and symptoms & $\begin{array}{c}\text { Spray } \\
\text { season } \\
(N=904)\end{array}$ & $\begin{array}{c}\text { Non-spray } \\
\text { season } \\
(N=1392)\end{array}$ & $\begin{array}{l}\text { Relative } \\
\text { risk }\end{array}$ & $\begin{array}{c}95 \% \\
\text { confidence } \\
\text { interval }\end{array}$ & Significance ${ }^{b}$ \\
\hline \multicolumn{6}{|l|}{ Neurobehavioral } \\
\hline $\begin{array}{l}\text { Fatigue }^{*} \\
\text { Dizziness }^{*} \\
\text { Insomnia }^{\circ} \\
\text { Blurred vision } \\
\text { Flushed face } \\
\text { Headache }^{*} \\
\text { Salivation }^{*} \\
\text { Excess sweating } \\
\text { Pallor } \\
\text { Hand tremor } \\
\text { Twitching of eyelids } \\
\text { Staggering } \\
\text { Irritability } \\
\text { Loss of consciousness } \\
\text { Convulsions }\end{array}$ & $\begin{array}{r}60.2 \\
20.8 \\
16.8 \\
15.5 \\
13.9 \\
13.2 \\
13.1 \\
3.7 \\
2.9 \\
2.0 \\
1.5 \\
0.9 \\
0.3 \\
0 \\
0\end{array}$ & $\begin{array}{r}20.4 \\
4.1 \\
2.4 \\
4.2 \\
0.3 \\
4.9 \\
0.8 \\
0.5 \\
0.7 \\
0.2 \\
0.3 \\
0.1 \\
0.9 \\
0 \\
0\end{array}$ & $\begin{array}{c}3.0 \\
5.1 \\
7.1 \\
3.7 \\
48 \\
2.7 \\
17 \\
7.3 \\
4.2 \\
9.2 \\
5.4 \\
12 \\
. \\
.\end{array}$ & $\begin{array}{c}2.6-3.3 \\
3.8-6.7 \\
4.9-10 \\
2.7-4.9 \\
18-131 \\
2.0-3.6 \\
9-30 \\
3.2-16 \\
2.2-8.2 \\
2.7-31 \\
1.8-16 \\
1.5-98 \\
. \\
.\end{array}$ & $\begin{array}{l}\text { S } \\
S \\
S \\
S \\
S \\
S \\
S \\
S \\
S \\
S \\
\text { NS } \\
\text { NS } \\
\text { NS }\end{array}$ \\
\hline \multicolumn{6}{|l|}{ Intestinal } \\
\hline $\begin{array}{l}\text { Nausea* } \\
\text { Queasiness } \\
\text { Belly pain } \\
\text { Constipation } \\
\text { Vomiting } \\
\text { Diarrhea }\end{array}$ & $\begin{array}{r}10.8 \\
5.4 \\
3.1 \\
1.9 \\
0.7 \\
0.3\end{array}$ & $\begin{array}{r}1.7 \\
1.1 \\
1.6 \\
0.5 \\
0 \\
0.5\end{array}$ & $\begin{array}{l}6.6 \\
5.0 \\
\cdot \\
\cdot \\
\cdot\end{array}$ & $\begin{array}{c}4.2-10 \\
2.8-8.9 \\
\cdot\end{array}$ & $\begin{array}{l}\text { S } \\
\text { S } \\
\text { NS } \\
\text { NS } \\
\text { NS } \\
\text { NS }\end{array}$ \\
\hline \multicolumn{6}{|l|}{ Respiratory } \\
\hline $\begin{array}{l}\text { Dry throat } \\
\text { Difficulty breathing* } \\
\text { Chest pain } \\
\text { Sore throat } \\
\text { Cough } \\
\text { Runny nose }\end{array}$ & $\begin{array}{r}29.9 \\
18.5 \\
13.6 \\
5.2 \\
4.4 \\
1.9\end{array}$ & $\begin{array}{l}0.8 \\
2.0 \\
2.7 \\
1.1 \\
6.2 \\
4.4\end{array}$ & $\begin{array}{l}38 \\
9.2 \\
5.1 \\
4.8 \\
\cdot \\
.\end{array}$ & $\begin{array}{l}21-69 \\
6.2-14 \\
3.6-7.3 \\
2.7-8.6\end{array}$ & $\begin{array}{c}S \\
S \\
S \\
S \\
\text { NS } \\
\text { NS }\end{array}$ \\
\hline \multicolumn{6}{|l|}{ Epithelial/mucosal surfaces } \\
\hline $\begin{array}{l}\text { Stinging eyes } \\
\text { ltchy skin } \\
\text { Red eyes } \\
\text { Burning nose } \\
\text { White rash and scaling } \\
\text { Burning eyes } \\
\text { ltchy eyes } \\
\text { Blisters } \\
\text { Red skin } \\
\text { Eye discharge } \\
\text { Burning tongue } \\
\text { Abraded skin }\end{array}$ & $\begin{array}{r}15.2 \\
9.3 \\
7.3 \\
6.5 \\
5.4 \\
5.1 \\
3.7 \\
1.5 \\
0.8 \\
0.7 \\
0.6 \\
0.3\end{array}$ & $\begin{array}{r}0.8 \\
4.6 \\
2.2 \\
0 \\
0.9 \\
0.1 \\
0.1 \\
0.3 \\
0.3 \\
0.9 \\
0.1 \\
0\end{array}$ & $\begin{array}{c}19 \\
2.0 \\
3.3 \\
\text { Undefined } \\
6.3 \\
35 \\
25 \\
. \\
. \\
. \\
. \\
.\end{array}$ & $\begin{array}{c}10-35 \\
1.5-2.8 \\
2.2-5.0 \\
3.4-12 \\
9-145 \\
6-105 \\
. \\
. \\
. \\
.\end{array}$ & $\begin{array}{c}S \\
S \\
S \\
S \\
S \\
S \\
S \\
N S \\
\text { NS } \\
\text { NS } \\
\text { NS } \\
\text { NS }\end{array}$ \\
\hline \multicolumn{6}{|l|}{ Muscle } \\
\hline $\begin{array}{l}\text { Muscle stiffness } \\
\text { Muscle weakness } \\
\text { Muscle cramps }\end{array}$ & $\begin{array}{r}54.0 \\
22.8 \\
1.8\end{array}$ & $\begin{array}{r}18.6 \\
13.5 \\
0.7\end{array}$ & $\begin{array}{l}2.9 \\
1.7 \\
.\end{array}$ & $\begin{array}{c}2.6-3.3 \\
1.4-2.0 \\
.\end{array}$ & $\underset{\text { S }}{S}$ \\
\hline
\end{tabular}

a Panel of 43 signs observed during the work and symptoms reported during an interview. The incidences in the spraying season represent only onset during or within a few hours of the spray operation (average number per spray operation 3.9, SD 2.5, range 0-15). The signs and symptoms printed in italics were used in further analyses to differentiate severity (average number per spray operation 2.1, SD 1.9, range 0 -10). Those with an asterix represent 12 signs and symptoms used by Keifer to diagnose pesticide poisoning (average number during spray operation 1.6, SD 1.2, range 0-6). (See text for details.)

${ }^{b} \mathrm{P}$-values are recorded as $\mathrm{S}$ for significant or NS for not significant. Given the large number of comparisons, we accept $\mathrm{P}=0.00125$ as significant by an approximate Bonferroni adjustment $(0.05 / 40)$.

c "Insomnia" reported the morning after the spray operation.

"Flushed face" was not included in the panel of 19 for concern that it could be nonspecifically diagnosed.

spraying frequency (SF) in the previous week to give a single index (SF/PI) that separated the observations into two groups: 353 spray operations with a low SF/PI score and 541 spray operations with a medium-to-high SF/PI score. With a low aggregate skin-exposure score, an increase in the SF/PI score was not associated with an increase in the frequency of signs and symptoms; as the skin-exposure score increased, however, an increased $\mathrm{SF} / \mathrm{PI}$ was associated with a greater frequency of signs and symptoms.

A dose-effect was seen between the increasing number of organophosphates used per spray operation 
Table 4. Trend analyses of exposure by frequency of signs and symptoms per spray operation.

\begin{tabular}{|c|c|c|c|c|c|}
\hline \multirow[t]{2}{*}{ Variable } & \multicolumn{3}{|c|}{ Percentage of spray operations } & \multirow[t]{2}{*}{ Chi-square $^{a}$} & \multirow[t]{2}{*}{ P-value } \\
\hline & $\begin{array}{l}0 \text { signs or } \\
\text { symptoms }\end{array}$ & $\begin{array}{c}1-3 \text { signs or } \\
\text { symptoms }\end{array}$ & $\begin{array}{l}4-10 \text { signs or } \\
\text { symptoms }\end{array}$ & & \\
\hline Sprayed since previous week & 63 & 75 & 84 & 25 & 0.00000 \\
\hline Wore unwashed clothing & 11 & 22 & 34 & 31 & 0.00000 \\
\hline Wore kneehigh/long pants & 35 & 42 & 49 & 7.6 & 0.006 \\
\hline Used bottle to mix pesticide "cocktail" & 27 & 37 & 52 & 20 & 0.00000 \\
\hline Feet wetted when pouring solution & 33 & 40 & 61 & 30 & 0.00000 \\
\hline Body wetted by solution & 56 & 79 & 92 & 76 & 0.00000 \\
\hline Shirt soaked with solution & 75 & 92 & 95 & 43 & 0.00000 \\
\hline WHO hazard grade IB/II (\% of pasticides ${ }^{c}$ ) & 41 & 44 & 48 & 8.3 & 0.0039 \\
\hline Multiple use of hazardous pesticides ${ }^{\circ}$ & 36 & 49 & 55 & 14.7 & 0.0001 \\
\hline
\end{tabular}

a Chi-square for linear trend.

With multiple independent comparisons, accept $\mathrm{P}=0.005$ as significant.

c Proportion of used that are classified as highly or moderately hazardous.

d Two or more grade IB/II pesticides (organophosphates and carbamates) mixed together.

Table 5. Regression analyses.

\begin{tabular}{|c|c|c|c|c|}
\hline Exposure variable ${ }^{a}$ & B coefficient & Beta & P-value ${ }^{b}$ & $\begin{array}{l}\text { Squared semipartial } \\
\text { correlation, type } 1^{\circ}\end{array}$ \\
\hline \multicolumn{5}{|l|}{894 spray operations } \\
\hline $\begin{array}{l}\text { Spray frequency } \\
\text { Skin exposure (six variables) } \\
\text { Pesticide index } \\
\text { Professional status }\end{array}$ & $\begin{array}{l}0.188 \\
0.234 \\
0.035 \\
0.331\end{array}$ & $\begin{array}{l}0.114 \\
0.342 \\
0.059 \\
0.053\end{array}$ & $\begin{array}{l}0.0004 \\
0.0001 \\
0.067 \\
0.095\end{array}$ & $\begin{array}{l}0.040 \\
0.113 \\
0.018 \\
0.003\end{array}$ \\
\hline \multicolumn{5}{|c|}{ Adjusted R-square $=0.17$, F-value $(\mathrm{df} 4,889)=46.5, P=0.0001$} \\
\hline $\begin{array}{l}\text { Spray frequency } \\
\text { Skin exposure (six variables) } \\
\text { Pesticide index } \\
\text { Professional status }\end{array}$ & $\begin{array}{l}0.339 \\
0.301 \\
0.036 \\
0.200\end{array}$ & $\begin{array}{l}0.185 \\
0.449 \\
0.060 \\
0.039\end{array}$ & $\begin{array}{l}0.003 \\
0.0001 \\
0.33 \\
0.52\end{array}$ & $\begin{array}{l}0.093 \\
0.186 \\
0.027 \\
0.001\end{array}$ \\
\hline Adjusted R-square $=0.29, \mathrm{~F}$-va & & & & \\
\hline
\end{tabular}

a The dependent variable was the attack rate of signs and symptoms with a relative risk for the spraying season greater than 3.0. Exposure variables included spray frequency in past week, an aggregate score of six variables of skin exposure, an index of pesticide hazard and number used, and status as professional sprayer. See the text for details.

b $P$ is the probability of the null hypothesis, $B=0$.

c Squared semipartial correlation type 1 represents the contribution of each variable to the coefficient of determination (R-square).

"Each farmer's attack rate of signs and symptoms and frequencies of exposure variables averaged to eliminate the "design effect" of multiple spray operations by the same persons. See the text for discussion.

and neurobehavioral signs and symptoms (including "flushed face"). Three groups — using none, one, and two or more organophosphates — showed a significantly increasing mean number of signs and symptoms: 1.06 $(\mathrm{N}=313, \mathrm{SD} 1.2), 1.14(\mathrm{~N}=396, \mathrm{SD} 1.4)$, and 1.46 $(\mathrm{N}=185, \mathrm{SD} 1.4)$, respectively $(\mathrm{F}$-value $=5.5$, $\mathrm{P}=0.004)$. We also considered dosage by examining four subgroups of respondents with extremes of experience: (i) 25 farmers who had never had any signs and symptoms from the panel of 19 (73 spray operations), (ii) 15 persons (44 spray operations) who always had four or more signs and symptoms per spray operation, (iii) 22 professional sprayers (86 spray operations), and (iv) 16 persons with hand tremor (18 spray operations). There was little overlap among these three groups, the maximum being four persons with hand tremor, who also belonged to the group with four or more signs or symptoms per spray operation. The second, third and fourth groups were significantly more exposed in several ways than the first group or the population as a whole was, but particularly in the use of pesticides. WHO hazard grade IB/II pesticides made up only $36 \%$ of the pesticides (mostly fenobucarb) used by the first group but comprised $59 \%$ of the pesticides used in each of the other groups' pesticides (mostly chlorpyrifos, triazophos, and fenobucarb); the differences were highly significant. The first group used twice as much grade 0 thiocarbamates (mainly mancozeb and propineb) as the other groups. In addition farmers in the first group were significantly older than those in the second group, by 10 years ( 41 versus 31 years, $\mathrm{P}<0.05$ ).

\section{Outcomes and home survey}

Of all of the respondents, only $24 \%$ took any medication, and less than $1 \%$ went to a health center with symptoms 


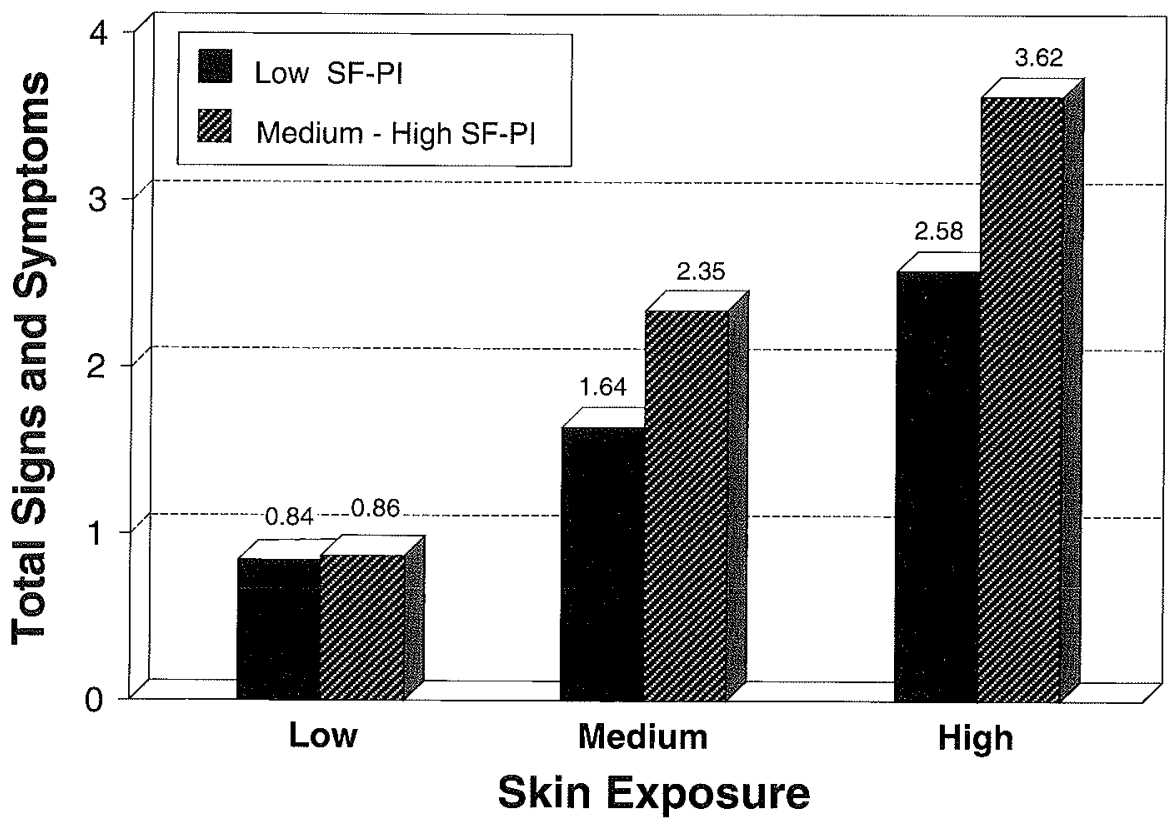

Figure 1. Relationship between the appearance of signs and symptoms per spray operation and an index of skin exposure. A joint score was calculated combining spraying frequency (SF) and the number and hazardousness of pesticides used (the pesticide index, ie, $\mathrm{PI}$ ) - see the text for details.

related to spraying. At least eight respondents required atropine treatment for pesticide poisoning at the local health centers in the course of the study (only one after an observed spray operation), but $9 \%$ of the respondents later recalled a serious episode of pesticide poisoning requiring medical attention in the past year. Visits to our respondents' homes showed that $84 \%$ stored agricultural chemicals there, $75 \%$ within the living or kitchen area and $82 \%$ easily within reach of children. Twenty-two percent of the containers were partially or completely unsealed, and $50 \%$ were leaking their contents. Over half of the respondents said they used the agricultural pesticides - much more concentrated than those licensed by the Department of Health for home use - for home and garden spraying. In $76 \%$ of the households, the wife or children washed the farmer's field clothing, mixed in with family laundry in nearly two-fifths of the households.

\section{Discussion}

Our study showed Indonesian farmers to be at considerable risk of acute pesticide poisoning when spraying their crops. Although the range of signs and symptoms would be classified as "mild" (14) - everyone could still walk $-21 \%$ of the respondents had three or more neurological, intestinal, or respiratory signs or symptoms per spray operation. If taken as a functional definition of poisoning, this attack rate is much higher than previously documented in Indonesia or elsewhere $(1,4)$. Our respondents tended to accept this level of illness as part of the work of farming. Only $9 \%$ mentioned being "poisoned by pesticides" over the past year, a level comparable to that of other recall surveys (4). We believe our study documents what is true "normal use" in third-world settings.

The study had several limitations. First, all interviewers and some of the respondents were aware of the nature of the study, and thus some of the positive relationship between exposure and illness could have been due to bias in reporting. Bias is unlikely to explain the entire relationship, much less the nuanced relationships, which are both biologically and epidemiologically plausible. Second, we did not measure biological markers in that acetylcholinesterase measu' ${ }^{\prime}$ ments in the field are subject to substantial problems an: errors and several samples, including a base-line measurement, are needed (19). They do not always correlate with signs and symptoms (12, 16 ), and they reflect poisoning with organophosphate pesticides only. Dermatologic patches can also give variable results under field conditions (20). Certain risks of pesticide toxicity are also unknown, such as the interactive effects of multiple pesticide exposures (21) or the possible potentiation of dermal uptake by volatile solvents in liquid formulations (22). Studies have also shown large interindividual variation in the amount of pesticide absorbed through the skin (23), complicating epidemiologic analyses of exposure. Finally, because we took a purposive sample, the study cannot represent the national incidence of pesticide poisoning, although what was observed did not seem atypical either in illness or in practice. 
The present study did show, by direct observation, those features of exposure associated with an increased risk of poisoning, some of which may be affected by intervention, for example, dermal exposure [especially when spills occur on bare skin and absorptive clothing and when unwashed garments are reused $(24,25)]$, the frequency of exposure (26), the relative potency of the pesticides used (27), and the simultaneous use of two or more organophosphate and carbamate pesticides. Of interest, and yet unexplained, are the positive correlations between these variables suggesting that some farmers are less cautious and others more cautious in all aspects of spraying.

Intervention or policy recommendations are needed. A common suggestion is training in the "safe use of pesticides" [ie, educate the farmer to wear protective clothing: "Gloves, apron and face shield . . . cotton work clothes, boots . . are sufficient protective equipment for workers for most pesticides" (28)]. In the tropics, however, adequate protective garb is certain to be too hot and thus unlikely to be used; the resulting perspiration if used can also increase the dermal absorption of pesticides (29). Even simple long-sleeved and long-legged workclothes can increase dermal absorption by direct contamination and occlusion (30). The considerable expense to obtain and resupply protective garb is, in any case, out of reach for most developing-country farmers. Neither would farmers necessarily respond to health education on the hazards of pesticides; focus group discussions with Indonesian farmers indicate that they believe frequent applications of strong pesticides are necessary to kill all insects and to prevent blemishes on cash crops. Sales agents representing large chemical industries, both Indonesian and foreign, reinforce this message regularly. Feeling ill appears to the farmers to be a necessary cost of doing business.

Farmers will, however, respond to the economics of farming. The use of pesticides fell by $62 \%$ in Indonesia between 1987 and 1990 as the government subsidy was eliminated (31), accompanied by a $10 \%$ increase in rice crop yields. IPM field schools demonstrate the agricultural, economic, and health logic of spraying less often and using fewer, better selected pesticides only when needed. Farmers who went through IPM training on rice crops not only sprayed $63 \%$ less often but also reduced their use of the more highly toxic organophosphate pesticides while still achieving the same yields as before (10). [Data from a follow-up study (by MK) indicate that the same is true for vegetable crops.] Effective pesticide regulation should be developed at the same time, however, particularly for the more toxic chemicals, through banning, stricter licensing and enforcement, higher prices, and perhaps user fees (32).

Two other findings from our study place the hazard of pesticides beyond simple "safe-use" intervention alone. First, professional sprayers engage in a dangerous occupation in which they have little control over conditions. Since they are paid by the fields they finish, they must spray frequently and hurriedly and must use whatever pesticides their employer chooses. They have yet to be targeted by IPM field schools, neither would they find the time to attend. This group needs attention also from the ministries of labor and health. Second, a household survey indicated a serious danger to family members from the storage and use of agricultural-strength pesticides in the home. Crawling children are at particular risk (26).

\section{Acknowledgments}

The authors are immensely grateful to the Tegal Secretariat team for their dedication and meticulous attention to detail. We also thank Tom Gillespie and Tom Mangione for their expert and timely technical assistance with the statistical analyses, Gerald A Pollock and Richard Clapp for providing information on pesticide toxicology, and Ian A Greaves for his close reading and editing of the manuscript. We also express our gratitude to Nandar for his fine touch in producing forms and reports. Finally, our sincere thanks go to all the farmers and professional sprayers who participated in this study.

\section{References}

1. World Health Organization (WHO). Public health impact of pesticides used in agriculture. Geneva: WHO, 1990:51,86.

2. Rosenstock L, Keifer M, Daniell WE, McConnell R, Claypool $\mathrm{K}$. Chronic central nervous system effects of acute organophosphate pesticide intoxication. Lancet 1991;338:223-7.

3. Pimental D, Acquay H, Biltonen M, Rice P, Silva M, Nelson $\mathrm{J}$, et al. Environmental and economic costs of pesticide use. Bioscience 1992;42:750-60.

4. Jeyaratnam J, Lun KC, Phoon WO. Survey of acute pesticide poisoning among agricultural workers in four Asian countries. Bull WHO 1987;65:521-7.

5. Loevinsohn ME. Insecticide use and increased mortality in rural central Luzon, Philippines. Lancet 1987;1:1359-62.

6. Ministry of Agriculture. Pesticida Untuk Pertanian dan Kehutanan [Pesticides for agriculture and forestry]. Jakarta (Indonesia): Ministry of Agriculture, 1991.

7. International Programme on Chemical Safety. The WHO recommended classification of pesticides by hazard and guidelines to classification 1992-1993. Geneva: United Nations Environment Programme, International Labour Organization, World Health Organization, 1992. WHO/PCS/92.14.

8. Soeharto. Presidential instruction no 3/November 5, 1986. (Jakarta).

9. Oka IN. Success and challenges of the Indonesian National Integrated Pest Management Program in the rice-based cropping system. Crop Protection 1991;10:163-65.

10. Mid-term Review Mission of the Government of Indonesia and FAO in Association with USAID. Impact study. UTF/ 
INS/067/INS, July 1991. Jakarta.

11. European Regional Office, World Health Organization (WHO). Organophosphorus pesticides: an epidemiologic study. Copenhagen: WHO European Regional Office, 1987. Environmental health series, no 22.

12. Ciesielski S, Loomis DP, Mims SR, Auer A. Pesticide exposures, cholinesterase depression, and symptoms among North Carolina farmworkers. Am J Public Health 1994;84:446 - 51.

13. Lwanga SK, Lemeshow $S$. Sample size determination in health studies. Geneva: World Health Organization, 1991:37.

14. Schlesselman JJ. Case-control studies: design, conduct, analysis. Oxford: Oxford University Press, 1982:145.

15. Tafuri J, Roberts J. Organophosphate poisoning. Ann Emerg Med 1987;16:193-202.

16. Baker, SR, Wilkinson CF, editors. The effect of pesticides on human health. Princeton, NJ: Princeton Scientific Publishing Co, 1990. Advances in modern environmental toxicology, vol 18.

17. Brown GW. P values. Am J Dis Child 1990;144:493-5.

18. Keifer M. Self-reported pesticide poisonings in Leon, Nicaragua: report of a survey [master's thesis]. Seatle, WA: University of Washington, 1989

19. Jeyaratnam J, Lun KC, Phoon WO. Blood cholinesterase levels among agricultural workers in four Asian countries. Toxicol Lett 1986;33:195-201.

20. Lavy TL, Mattice JD. Progress in pesticide exposure studies and future concerns. Toxicol Lett 1986;33:61-71.

21. Miyaoka T, Tsuda S, Shirasu X. Mechanism of potentiation of BPMC toxicity by fenthion pretreatment in mice. J Pharmacobiodyn 1986;9:697-703.

22. Mathias CGJ, Hinz RS, Guy RH, Maibach HI. Percutaneous absorption: interpretation of in vivo data and risk assessment In: Honeycutt RC, Zweig G, Ragsdale NN, editors. Dermal exposure related to pesticide use: discussion of risk assessment, Washington, DC: American Chemical Society, 1985:3-17. ACS symposium series, no 273.

23. Paustenbach DJ, Leung $\mathrm{H}-\mathrm{W}$. Techniques for assessing the health risks of dermal contact with chemicals in the environ- ment. In: Wang, RGM, Knaak JB, Maibach, HI, editors. Dermal and inhalation exposure and absorption of toxicants. Boca Raton, FL: CRC Press, 1993:347.

24. McConnell R, Anton AFP, Magnotti R. Crop duster aviation mechanics: high risk for pesticide poisoning. Am J Public Health 1990:80:1236-9.

25. Davies JE, Freed VH, Enos HF, Duncan RC, Barquet A, Morgade $\mathrm{C}$, et al. Reduction in pesticide exposure with protective clothing for applicators and mixers. J Occup Med $1982 ; 24: 464-8$.

26. Plestina R. Prevention, diagnosis, and treatment of insecticide poisoning. Geneva: World Health Organization, 1984. WHO/ $\mathrm{VBC} / 84.889$.

27. Coye MJ, Barnett PG, Midtling JE, Velasco AR, Romero P, Clements CL, et al. Clinical confirmation of organophosphate poisoning of agricultural workers. Am J Ind Med 1986;10:399-409.

28. Report of fifth FAO/UNEP joint meeting on prior informed consent (PIC), Rome, Italy, 26-30 October, 1992:20.

29. Nigg HN, Beier RC, Carter O, Chaisson C, Franklin C, Lavy $T$, et al. Exposure to pesticides. In: Baker SR, Wilkinson CF, editors. The effect of pesticides on human health. Princeton, NJ: Princeton Scientific Publishing Co, 1990:44. Advances in modern environmental toxicoloqy, vol 18.

30. Wester RC, Maibach HI. Dermal decontamination and percutaneous absorption. In: Bronaugh RL, Maibach HI, editors. Percutaneous absorption; mechanics, methodology, drug delivery. New York, NY: Marcell Dekker, 1985:327-33.

31. Data from Ministry of Finance. Cited by J Tarrant in FAO/ World Bank preparation report, vol II, part II, working paper 4 (Environment) 1992.

32. Zilberman D, Schmitz A, Casterline G, Lichtenberg E, Siebert JB. The economics of pesticide use and regulation. Science 1991;253:518-22

Received for publication: 27 December 1993 